\title{
Blood: Can't live with it, can't live without it
}

\author{
Jennifer M. Banayan, MD, and Mark A. Chaney, MD
}

\footnotetext{
From the Department of Anesthesia and Critical Care, University of Chicago, Chicago, Ill.

Disclosures: Authors have nothing to disclose with regard to commercial support.

Received for publication March 31, 2016; accepted for publication April 1, 2016; available ahead of print April 23, 2016.

Address for reprints: Mark A. Chaney, MD, Department of Anesthesia and Critical Care, University of Chicago, 5841 S Maryland Ave MC4028, Chicago, IL (E-mail: mchaney@dacc.uchicago.edu).

J Thorac Cardiovasc Surg 2016;152:18-9

0022-5223/\$36.00

Copyright (C) 2016 Published by Elsevier Inc. on behalf of The American Association for Thoracic Surgery http://dx.doi.org/10.1016/j.jtcvs.2016.04.017
}

The literature on transfusion-related morbidity and mortality in cardiac surgical patients is vast. Despite traditional teaching that patients with coronary artery disease benefit from hematocrits greater than $30 \%$, the majority of studies published demonstrate increases in short- and long-term mortalities among cardiac surgical patients receiving packed red blood cells (pRBCs). ${ }^{1-3}$ A number of studies warn that exposure to any quantity of transfused blood is associated with decreased survival after coronary artery bypass grafting. ${ }^{3,4}$ In contrast, The New England Journal of Medicine published a randomized, controlled study in 2015 that revealed a decrease in survival among those cardiac surgical patients randomly allocated to a restrictive transfusion threshold (hemoglobin $<7.5 \mathrm{~g} / \mathrm{dL}$ ) relative to a liberal transfusion threshold $(<9 \mathrm{~g} / \mathrm{dL})$. Despite the increase in mortality in the restrictive group, no difference with respect to postoperative morbidity, such as sepsis, stroke, or acute kidney injury, was observed. ${ }^{5}$

The study in this issue of The Journal by Bjursten and colleagues $^{6}$ from Lund, Sweden, presents a large (9907 patients in 11 years) retrospective analysis from a single institution detailing the relationship between blood product use and mortality in patients after coronary artery bypass grafting, aortic valve replacement, or both procedures. Bjursten and colleagues ${ }^{6}$ found that the use of sexmismatched pRBCs increased postoperative mortality. They also discovered that transfusing small amounts of leukocyte-depleted (LD) pRBCs did not affect mortality, whereas transfusion of any amount of non-LD pRBCs or of large amounts of LD pRBCs increased postoperative mortality. Finally, in a contrast with previous investigations, they found that increased age of blood products administered was not associated with increased postoperative mortality.

Strengths of this study include its size, the duration of follow-up, and the use of Sweden's national tax registry for accurate tracking of patient deaths. This study is an important addition to the extensive transfusion literature, because it identifies potential confounding risk factors such as sex-mismatching and use of non-LD products. Although previous studies have demonstrated an increase the results.

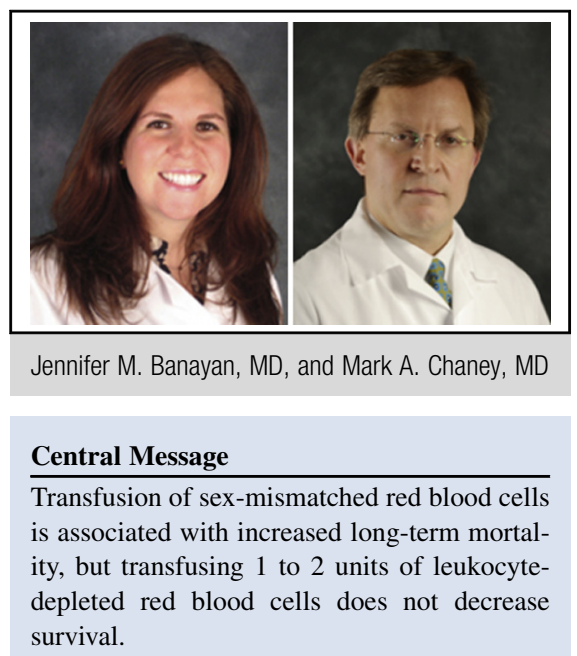

See Article page 223.

See Editorial Commentary page 233.

in mortality for patients transfused simply 1 unit of pRBCs, ${ }^{2}$ this study reveals that transfusing 1 to 2 units of LD pRBCs does not increase mortality.

The primary weakness of this study is its retrospective design and the inherent limitations associated with that process, including reliance on accurate data collecting, lack of quality data, and the difficulty of identifying associations versus causations when examining results. In addition, this study relies on advanced statistical analysis, often a criticism of retrospective database reviews. On a positive note, however, one of the article's coauthors is a professor of epidemiology, and the manuscript underwent statistical review by one of The Journal's statistical editors. Finally, Bjursten and colleagues ${ }^{6}$ did not address secondary morbidity outcomes. Cardiac surgery's mortality is multifactorial, and secondary outcomes would have strengthened

Overall, this article by Bjursten and colleagues ${ }^{6}$ is an important adjunct to the literature on transfusion during cardiac surgery, because it expands on the knowledge of potential sex-mismatch risk and reiterates the potential benefits of limiting transfusion to LD pRBCs. This study suggests that sex-mismatched blood transfusions may create a high enough risk to necessitate a change in transfusion protocols. As for leukocyte depletion, many countries already have universal leukoreduction strategies, including Canada, Britain, and Germany. Perhaps this article by Bjursten and colleagues ${ }^{6}$ calls for the United States to pursue the same policy. 


\section{References}

1. Murphy GJ, Reeves BC, Rogers CA, Rizvi SI, Culliford L, Angelini GD. Increased mortality, postoperative morbidity, and cost after red blood cell transfusion in patients having cardiac surgery. Circulation. 2007;116:2544-52.

2. van Straten AH, Bekker MW, Soliman Hamad MA, van Zundert AA, Martens EJ, Schönberger JP, et al. Transfusion of red blood cells: the impact on short-term and long-term survival after coronary artery bypass grafting, a ten-year follow-up. Interact Cardiovasc Thorac Surg. 2010;10: $37-42$.

3. Surgenor SD, Kramer RS, Olmstead EM, Ross CS, Sellke FW, Likosky DS, et al. The association of perioperative red blood cell transfusions and decreased long-term survival after cardiac surgery. Anesth Analg. 2009;108: 1741-6.

4. Koch CG, Li L, Duncan AI, Mihaljevic T, Loop FD, Starr NJ, et al. Transfusion in coronary artery bypass grafting is associated with reduced long-term survival. Ann Thorac Surg. 2006;81:1650-7.

5. Murphy GJ, Pike K, Rogers CA, Wordsworth S, Stokes EA, Angelini GD, et al. Liberal or restrictive transfusion after cardiac surgery. N Engl J Med. 2015;372: 997-1008. Erratum in N Engl J Med. 2015;372:2274.

6. Bjursten H, Dardashti A, Björk J, Wierup P, Algotsson L, Ederoth P. Transfusion of sexmismatched and non-leukocyte-depleted red blood cells in cardiac surgery increases mortality. J Thorac Cardiovasc Surg. 2016;152:223-32. 